\title{
Pengaruh Biourine dan Fungi Mikoriza Arbuskula terhadap Hasil Hijauan, Protein Kasar serta Fosfor Rumput Kumpai (Hymenachne amplexicaulis (Rudge) Nees) pada Lahan Bekas Tambang Batubara
}

\section{Effects of Biourine and Arbuscular Mycorrhizal Fungi on Forage Results, Crude Proteins and Phosphorus of Kumpai Grass (Hymenachne amplexicaulis (Rudge) Nees) on the Ex- Coal Mining Land}

\author{
H. Syafria ${ }^{1 *}$ dan N. Jamarun ${ }^{2}$ \\ ${ }^{1}$ Fakultas Peternakan Universitas Jambi, Kampus Pinang Masak Mendalo Jambi, 36361 \\ ${ }^{2}$ Fakultas Peternakan Universitas Andalas, Kampus Unand Limau Manis Padang, 25163 \\ *Corresponding E-mail: hardi@unja.ac.id
}

(Diterima: 10 Oktober 2020; Disetujui: 25 Januari 2021)

\begin{abstract}
ABSTRAK
Penelitian ini bertujuan untuk mengetahui pengaruh biourin dan jamur mikoriza arbuskular terhadap hasil hijauan pakan, kandungan protein kasar dan fosfor rumput kumpai di lahan bekas tambang batubara. Penelitian dilakukan dalam Rancangan Acak Kelompok, dengan 6 perlakuan dan 3 ulangan. Perlakuan terdiri dari: (A) $0 \%$ biourine + FMA 0 gram / rumpun, (B) $0 \%$ biourine +20 gram / rumpun FMA, (C) $30 \%$ biourine + FMA 0 gram / rumpun, (D) 30\% biourine + FMA 20 gram / rumpun, (E) $45 \%$ biourine + FMA 0 gram / rumpun dan (F) 45\% biourine + FMA 20 gram / rumpun. Variabel yang diamati adalah hasil bahan kering, protein kasar dan fosfor rumput kumpai. Hasil penelitian menunjukkan bahwa perlakuan berpengaruh nyata $(\mathrm{P}<0,05)$ terhadap hasil bahan kering, protein kasar dan fosfor. Dari hasil penelitian dapat disimpulkan bahwa perlakuan F (biourine 45\% + FMA 20 gram / rumpun) menghasilkan bahan kering terbaik $(2253,60 \mathrm{~kg} / \mathrm{ha})$, protein kasar $(14,55 \%)$ dan fosfor $(1,12 \%)$.
\end{abstract}

Kata kunci: biourin, Mikoriza, hasil, rumput Kumpai

\section{ABSTRACT}

This study aims to determine the effect of biourine and arbuscular mycorrhizal fungi on forage results, crude protein content, and phosphorus of kumpai grass in the ex-coal mining land. The study was conducted in a randomized block design, with six treatments and three replications. The treatments consist of: (A) $0 \%$ biourine + FMA 0 gram/clump, (B) $0 \%$ biourine +20 gram/clump FMA, (C) 30\% biourine + FMA 0 gram/clump, (D) 30\% biourine + FMA 20 gram/clump, (E) 45\% biourine + FMA 0 gram/clump and (F) $45 \%$ biourine + FMA 20 gram/clump. Variables observed were the results of dry matter, crude protein, and phosphorus of kumpai grass. The results showed that the treatment had a significant effect $(P<0.05)$ on dry matter, crude protein, and phosphorus. From the results of this study, it can be concluded that the treatment of $F$ (biourine 45\% + FMA 20 gram/clump) produces the best dry matter $(2253.60 \mathrm{~kg} / \mathrm{ha}$ ), crude protein (14.55\%), and phosphorus (1.12\%).

Keywords: biourine, Mycorrhizae, yields, Kumpai grass

\section{PENDAHULUAN}

Sapi jantan bobot $\pm 300 \mathrm{~kg}$ mampu menghasilkan urine sekitar 8-12 liter perhari, sedangkan sapi betina bobot $\pm 250 \mathrm{~kg}$ menghasilkan urine sekitar 7,5-9 liter perhari
(Adijaya et al., 2008). Urine sapi mengandung Indole Acetic Acid (IAA) adalah senyawa dari golongan auksin. IAA berpengaruh terhadap pertumbuhan tanaman (Bidwel, 1979). Urine yang diolah menjadi biourine bermanfaat untuk pupuk organik. karena 
mengandung unsur hara meskipun dalam jumlah sedikit. Hasil penelitian Syafria dan Jamarun (2018) urine diolah dengan sistem aerasi selama 6 jam dan difermentasi selama 2 minggu menghasilkan kandungan unsur hara $\mathrm{N}(0,50 \%), \mathrm{P}(10,44 \%), \mathrm{K}(1,18 \%), \mathrm{C}(10,48$ $\% 0, \mathrm{C} / \mathrm{N}$ ratio $(19,96)$ dan $\mathrm{pH}(7,0)$.

Fungi mikoriza arbukula dapat mengatasi keracunanAlyang merupakanfaktor pembatas pertumbuhan tanaman pada tanah marginal. Sundari et al. (2011) pemanfaatn mikoriza sebagai pupuk dapat menghindari kerusakan tanah akibat penggunaan pupuk kimia. Mmenurut Prihastuti et al. (2007) fungi mikoriza arbuskula merupakan salah satu mikroorganisme yang berperan penting bagi tanaman, diantaranya meningkatkan penyerapan hara tanah, penghalang biologis infeksi patogen akar, meningkatkan ketersediaan air, dan hormon tumbuh tanaman.

Rumput lokal kumpai (Hymenachne amplexicaulis (Rudge) Ness ) adalah jenis hijauan lokal cukup potensial sebagai sumber hijauan pakan ternak ruminansia.. Hasil penelitian Syafria (1996) dan Syafria (1998) kandungan protein kasar rumput kumpai pada kondisi alami lebih kurang 11,20 $\%$. Hasil penelitian Syafria dan Jamarun (2018) perlakuan biourine $45 \%+20$ gram FMA/rumpun menghasilkan protein kasar $(15,35 \%)$, dan hasil bahan kering $(160,44 \mathrm{~g} /$ rumpun).

Menurut Dinas Sumber Daya Energi dan Mineral Propinsi Jambi (2010) luas wilayah izin usaha penambangan batu bara mencapai lebih kurang seluas 757.241,10 hektar. Lahan bekas penambanagn memiliki kondisi tanah kahat unsur hara terutama unsur $\mathrm{N}$ dan $\mathrm{P}$, reaksi tanah masam, top soil tipis, miskin kandungan bahan organik dan adanya gejala toksisitas $\mathrm{Al}$ dan Mn (Kartika et al., 2006). Pemberian pupuk kimia meskipun meningkatkan hasil, tetapi memerlukan biaya yang mahal dan penggunaan dalam jangka panjang dapat merusak lingkungan. Penggunaan pupuk organik merupakan alternatif sangat diperlukan, karena mengandung unsur hara yang dibutuhkan tanaman.

Berdasarkan kerngka pemikiran diatas, maka dilakukan penelitian pemberian biourine dan fungi mikoriza arbuskula pada tanah bekas tambang batubara, dengan tujuan untuk mempelajari dan membuktikan bahwa pemanfaatan biourin dan fungi mikoriza arbuskula berpengaruh terhadap hasil hijauan, kandungan protein kasar dan fosfor rumput kumpai.

\section{METODE}

\section{Tempat, Waktu dan Materi Penelitian}

Penelitian dilakukan di areal tambang batubara PT. Gea Lestari Jambi. Analisa bahan kering hijauan di Laboratorium Nutrisi dan Makanan Ternak Fakultas Peternakan Universitas Jambi. Analisa protein kasar dan fosfor di Laboratorium Balai Penelitian Ternak Ciawi Bogor. Penelitian berlangsung dari bulan Mei sampai dengan September 2019.

Hijauan yang digunakan adalah rumput kumpai dengan bahan tanam berupa potongan batang (stek), masing-masing terdiri dari 3 stek. Pupuk biourine berasal dari urine sapi yang diolah dengan system aerasi air mengalir dan difermentasi selama 2 minggu (Syafria dan Jamarun, 2018). Sebagai pupuk dasar digunakan pupuk TSP $\left(45 \% \mathrm{P}_{2} \mathrm{O}_{5}\right)$, $\mathrm{KCl}\left(60 \% \mathrm{~K}_{2} \mathrm{O}\right)$, Urea $(46 \% \mathrm{~N})$ dan kapur pertanian $\mathrm{CaCO}_{3}$. Fungi mikoriza arbuskula yang digunakan jenis multiple spora dengan merk dagang Cemiko I, diperoleh dari Laboratorium Ilmu Tanah Fakultas Pertanian Universitas Andalas.

Peralatan yang digunakan antara lain cangkul, gunting rumput, mistar, penyiram, kantong plastik, amplop, timbangan, dan peralatan untuk analisa hijauan.

\section{Metode Penelitian}

Penelitian dilakukan mengguakan rancangan acak kelompok dengan 6 perlakuan 3 ulangan. Perlakuan terdiri dari: (1) biourine 
$0 \%$ + FMA 0 g/rumpun; (2) biourine $0 \%$ +FMA 20 g/rumpun; (3) biourine $30 \%+$ FMA 0 g/rumpun; (4) biourine $30 \%+$ FMA 20 g/rumpun; (5) biourine $45 \%+$ FMA 0 g/rumpun; (6) biourine $45 \%$ + FMA $20 \mathrm{~g} /$ rumpun

Peubah yang diamati hasil bahan kering hijauan, kandungan protein kasar dan fosfor hijauan. Pengolahan data dilakukan secara statistik dalam rancangan acak kelompok. Hasil analisis ragam yang berpengaruh nyata dilanjutkan dengan Uji Jarak Berganda Duncan (Steel dan Torrie, 1991).

\section{Pelaksanaan Penelitian}

Tahap pertama pelaksanaan penelitian adalah pengukuran luas tanah yang digunakan, kemudian dilakukan pengolahan tanah sampai gembur. Selanjutnya pembuatan petak-petak percobaan, ukuran $1 \mathrm{~m} \times 2 \mathrm{~m}$, jarak antar blok $1 \mathrm{~m}$ dan antar petak $0,50 \mathrm{~m}$.

Pupuk dasar yang digunakan adalah TSP

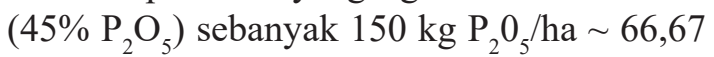
$\mathrm{g} \mathrm{TSP} /$ petak); $\mathrm{KCl}\left(60 \% \mathrm{~K}_{2} \mathrm{O}\right)$ sebanyak 100 $\mathrm{kg} \mathrm{K}_{2} \mathrm{O} / \mathrm{ha} \sim 33,33 \mathrm{~g} \mathrm{KCl} /$ petak); Urea (46\% N) sebanyak $200 \mathrm{~kg} \mathrm{~N} / \mathrm{ha} \sim 88,82 \mathrm{~g}$ Urea/ petak; dan kapur pertanian $\mathrm{CaCO}_{3}$ sebanyak 2 ton/ha $\sim 400 \mathrm{~g} /$ petak. Pemberian pupuk dasar dan kapur diberikan bersamaan, dengan cara ditebar ketanah dalam petak percobaan, kemudian diaduk menggunakan garu agar homogen. Tanah yang sudah diberikan pupuk dasar diinkubasi selama seminggu sampai waktu penanaman.

Sebelum tanam bahan tanam berupa potongan batang (stek) dengan panjang 25 $\mathrm{cm}$ (terdiri dari 2 ruas dan 3 buku), terlebih dahulu disterilkan dengan cara direndam dalam larutan 2,6\% $\mathrm{NaOCl}$ selama lima menit kemudian dibilas dengan air. Pemberian fungi mikoriza arbuskula bersamaan dengan penanaman rumput, dengan cara memasukkan inokulum kedalam setiap lubang tanam sedalam lebih kurang $8 \mathrm{~cm}$ (Husen, 2012). Sedangkan pupuk biourine diberikan setelah tanaman berumur lebih kurang satu minggu.

Pemangkasan tanaman untuk penyamarataan guna memperoleh awal pertumbuhan yang seragam, dan mengurangi pengaruh keragaman bibit, dilakukan setelah tanaman berumur tiga minggu. Pemanenan hijauan dilakukan sebanyak dua kali dengan interval pemotongan 40 hari setelah penyamarataan, dengan intensitas $15 \mathrm{~cm}$ diatas permukaan tanah.

Untuk menghindari pengaruh efek pinggir, maka pengamatan setiap peubah dilakukan pada tanaman sampel yang berada ditengah petak percobaan. Hasil bahan kering hijauan perpetak dikonversikan ke hasil bahan kering dalam satuan $\mathrm{kg} / \mathrm{ha}$. Analisis bahan kering hijauan menurut metode AOAC (1975), penentuan protein kasar dengan metode Kjeldhal (Ivan et al., 1974).

\section{HASIL DAN PEMBAHASAN}

\section{Hasil BahanKering Hijauan}

Terdapat perbedaan yang nyata $(\mathrm{P}<0.05)$ antar perlakuan terhadap hasil bahan kering hijauan, sehingga ada variasi nilai hasil bahan kering yang berbeda pada setiap perlakuan (Tabel 1). Hasil bahan kering hijauan terendah diperoleh pada perlakuan A $(1651,65 \mathrm{~kg} / \mathrm{ha})$, sedangkan yang tertinggi diperoleh pada perlakuan F $(2253,60 \mathrm{~kg} / \mathrm{ha})$.

Hasilbahankeringhijauaneratkaitannya dengan pertumbuhan tanaman, dan konsumsi oksigen akar tanaman bermikoriza 2-4 kali lebih besar dibanding tidak bermikoriza, sehingga lebih mampu menyerap garamgaram mineral dan suplai ion hidrogen yang dapat dipertukarkan. Hal ini menyebabkan akar tanaman bermikoriza memiliki energi kinetik penyerapan yang lebih besar. Unsur hara dan air yang terakumulasi di sekitar perakaran tanaman akan ditranslokasikan kehifa internal, kemudian kejaringan inang melalui arbuskular intraseluler. Menurut Beinroth (2001) mikoriza mampu meningkatkan penyerapan hara dan air dari dalam tanah, sehingga tanaman menghasilkan sel-sel baru dpertumbuhan, memperbaiki agregat tanah sehingga proses aliran masa berlangsung dengan baik. Hasil bahan kering hijauan 
Tabel 1. Hasil Bahan Kering Hijauan, Protein Kasar dan Fosfor Rumput Kumpai pada berbagai Perlakuan Biourine dengan Fungi Mikoriza Arbuskula

\begin{tabular}{|c|c|c|c|}
\hline Perlakuan (Biourine + FMA) & $\begin{array}{l}\text { Hasil Bahan Kering } \\
\text { Hijauan }(\mathrm{kg} / \mathrm{ha})\end{array}$ & $\begin{array}{c}\text { Protein Kasar } \\
(\%)\end{array}$ & Fosfor $(\%)$ \\
\hline A. biourine $0 \%+$ FMA 0 gram/rumpun & $1.651,65^{\mathrm{e}}$ & $10,20^{\mathrm{c}}$ & $0,21^{\mathrm{d}}$ \\
\hline B. biourine $0 \%+$ FMA 20 gram/rumpun & $2.001,25^{\mathrm{c}}$ & $12,02^{b}$ & $0,70^{\mathrm{b}}$ \\
\hline C. biourine $30 \%+$ FMA 0 gram/rumpun & $1.827,50^{\mathrm{d}}$ & $11,50^{\mathrm{b}}$ & $0,45^{\mathrm{c}}$ \\
\hline D. biourine $30 \%+$ FMA 20 gram/rumpun & $2.151,00^{b}$ & $14,23^{\text {a }}$ & $1,08^{\mathrm{a}}$ \\
\hline E. biourine $45 \%+$ FMA 0 gram/rumpun & $1.852,20^{\mathrm{d}}$ & $11,75^{b}$ & $0,50^{\mathrm{b}}$ \\
\hline F. biourine $45 \%+$ FMA 20 gram/rumpun & $2.253,60^{\mathrm{a}}$ & $14,55^{\mathrm{a}}$ & $1,12^{\text {a }}$ \\
\hline
\end{tabular}

Keterangan: Huruf kecil yang berbeda pada kolom yang sama menunjukkan berbeda nyata $(\mathrm{P}<0,05)$ berdasarkan uji jarak berganda Duncan

juga merupakan manifestasi dari berbagai faktor yang mempengaruhi pertumbuhan dan perkembangan tanaman, antara lain faktor genetis dan lingkungan (Bidwell, 1979). Oleh karena itu, pada kondisi iklim yang sama, maka kesuburan tanah lebih memberikan pengaruh terhadap pertumbuhan tanaman (Syafria, 2001; Mardani, 2004). Husin et al. (2012) menyatakan bahwa akar tanaman bermikoriza akan cepat pulih kembali selama periode kekurangan air, karena hifanya mempunyai kemampuan menyerap air dari pori-pori tanah pada saat tanaman tidak mampu lagi menyerap air. Hasil penelitian Syafria (2018) menyimpulkan bahwa pemberian biourin dan fungi mikoriza arbuskula pada tanah bekas tambang batubara berpengaruh terhadap pertumbuhan dan hasil rumput kumpai.

\section{Protein Kasar}

Dari Tabel 1 juga menunjukkan perbedaan nyata $(\mathrm{P}<0,05)$ antar perlakuan terhadap protein kasar. Terdapat variasi nilai kandungan protein kasar setiap perlakuan, namun secara statistik tidak menunjukkan perbedaan yang nyata $(\mathrm{P}>0,05)$ antara perlakuan $\mathrm{D}$ dan $\mathrm{F}$ terhadap protein kasar. Kandungan potein kasar terendah pada perlakuan A (10,20\%), sedangkan tertinggi pada perlakuan $\mathrm{F}(14,55 \%)$.

Semakin meningkat konsentrasi biourine, mampu meningkatkan protein kasar hijauan. Hal ini disebabkan karena hifa dari fungi mikoriza arbuskula yang berasosiasi dengan akar, membantu tanaman menyerap hara dalam tanah dan air dari pori-pori tanah lebih banyak. Mikoriza menginfeksi perakaran tanaman dan membentuk jalinan hifa secara intensif, sehingga meningkatkan penyerapan hara terutama fosfor untuk metabolism karbohidrat, memperbaiki struktur tanah, sehingga pada tahap selanjutnya berpengaruh terhadap kualitas hijauan. Spora fungi mikoriza arbuskula mengandung nitratreduktase sehingga hifa eksternalnya mempunyai kapasitas penyerapan nitrat (Bago et al., 1996). Hifa ini mampu meningkatkan penyerapan hara $\mathrm{N}, \mathrm{Ca}$ dan $\mathrm{Mg}$ yang bersifat mobil (Hapsoh, 2008), dan juga meningkatkan serapan hara mikro $\mathrm{Zn}, \mathrm{Cu}$, dan B (Smith and Read, 2008).

\section{Fosfor}

Terdapat perbedaan nyata $(\mathrm{P}<0,05)$ antar perlakuan terhadap kandungan fosfor (Tabel 1). Terlihat adanya variasi nilai kandungan fosfor pada setiap perlakuan, namun secara statistik tidak berbeda nyata $(\mathrm{P}>0,05)$ antara perlakuan $\mathrm{C}$ dan $\mathrm{E}$ dan antara perlakuan D dan F. Kandungan fosfor terendah pada perlakuan A $(0,21 \%)$, yang tertinggi pada perlakuan $\mathrm{F}(1,12 \%)$.

Kandungan fospor hijauan diperlukan untuk memperoleh gambaran terhadap kemampuan tanaman mengabsorpsi unsur fosfor yang sering merupakan salah satu faktor pembatas dalam meningkatkan produktivitas tanaman. Hal ini dikarenakan ion posfat 
anorganik akan bersenyawa dengan koloid tanah atau terfiksasi dalam bentuk Fe-P dan Al-P yang menjadikan relatif tidak mobil bagi tanaman. Meningkatnya kandungan fosfor pada tanaman bermikoriza, karena hifa dari fungi mikoriza mampu membantu tanaman menyerap unsur hara dalam tanah dan air dari pori-pori tanah. Mikoriza menginfeksi system perakaran tanaman inang dengan membentuk jalinan hifa, sehingga tanaman mampu meningkatkan penyerapan hara fosfat. MenurutBeinroth(2001) infeksi mikoriza pada tanaman dapat menghasilkan enzim fosfatase, yang berfungsi meningkatkan ketersediaan fosfat yang rendah ketersediaannya pada lahan marginal. Hifa bermikoriza didalam tanah dapat meningkatkan serapan unsur fosfor hingga $8 \mathrm{~cm}$ dari akar, sehingga suplai fosfor terhadap tanaman lebih besar. Mikoriza mampu memanfaatkan fosfor yang terikat oleh phytat secara efisien, karena adanya enzim fosfatase (Smith and Read, 2008). Fosfatase dapat menghidrolisis berbagai senyawa fosfor organik (Tarafdar and Claassen, 2001), dan enzim ini melimpah di rhizosphere saat tanaman kekurangan fosfor (Yun and Kaeppler, 2001; Wasaki et al., 2003).

\section{KESIMPULAN}

Perlakuan F (biourine 45\% + FMA $20 \mathrm{~g}$ / rumpun) menghasilkan bahan kering hijauan $(2253,60 \mathrm{~kg} / \mathrm{ha})$, protein kasar $(14,55 \%)$ dan fosfor $(1,12 \%)$ tertinggi dari perlakuan lainnya.

\section{UCAPAN TERIMAKASIH}

Ucapan terima kasih penulis kepada Direktorat Riset dan Pengabdian pada Masyarakat Direktorat Jenderal Penguatan Riset dan Pengembangan, Kementerian Riset, Teknologi, dan Pendidikan Tinggi atas persetujuan dana penelitian ini.

\section{DAFTAR PUSTAKA}

Adijaya, I.N., Sudaratmaja, I.G.A.K., Mahaputra, I.K., Trisnawati, N.W., Suharyanto, Guntoro, S., Rinaldi, J., Elizabeth, D.A.A., Priningsih, P.Y., dan Rachim, A. 2008. Prima Tani LKDRIK Desa Sanggalangit, kec. Gerogak, Kab. Buleleng, Bali. Laporan. Balai Pengkajian Teknologi Pertanian, Denpasar.

AOAC. 1975. Official Methods of the Analysis of the Association of the Official Agricultural Chemists. 9 th.Ed., Washington.

Bago, B., H. Vierheilig, Y. Piche, and C. Azcon-Aguilar. 1996. Nitratdepletion and $\mathrm{pH}$ changes induced by the extraradicamycelium of the arbuscular mycorrhizal fungus Glomus Intraradices in Monoxenic Culture. New Phytol.133:273-280.

Beinroth, F. H. 2001. Land resources for forage production in the tropics In Sotomayor-Rios A. Pitman Wd (eds) Tropical Forage Plants Development and Use CRC Press. Pp 3 - 15.

Bidwell, R.G.S. 1979. Plant Physiology. Ed 2. Macmillan Publishing Co. Inc. New York.

Dinas Energi dan Sumber Daya Mineral Provinsi Jambi. 2019. Data Base Pertambangan Batubara. Badan Pusat Statistik Provinsi Jambi. Jambi.

Hapsoh. 2008. Pemanfaatan FMA pada budidaya kedelai dilahan kering.USUMedan.

Husin, E. F., A. Syarif, dan Kasli. 2012. Mikoriza sebagai Pendukung Sistem Pertanian Berkelanjutan dan Berwawasan Lingkungan. Andalas University Press. Padang.

Ivan, H., O. J. Clack, and G. J. White. 1974. Kjeldahl Nitrogen Determination. Dalam: Short Course on Poultry Production., Udayana University. 
Kartika, E. 2006. Tanggap Pertumbuhan, Serapan Hara dan Karakter Morfofisiologi terhadap Cekaman Kekeringan pada Bibit Kelapa Sawit yang Bersimbiosis dengan CMA. Disertasi Sekolah Pascasarjana Institut Pertanian Bogor. Bogor. 188p.

Mardani, Y. D. 2004. Pengaruh pupuk organik pada lahan marginal bekas penambangan pasir terhadap produktivitas kacang tanah. Fakultas Pertanian Institut Pertanian Yogyakarta.

Prihastuti. 2007. Isolasi dan karakterisasi mikoriza vesikular-arbuskula di lahan kering masam, Lampung Tengah, Berk. Penel. Hayati: 12 (99-106).

Smith, S. E. and D. J. Read. 2008. Mycorrhizal symbiosis. Third edition: Academic Press. Elsevier Ltd. New York, London, Burlington, San Diego. 768p.

Steel, R. G. D, and J. H. Torrie. 1991. Prinsip dan Prosedur Statistik. Suatu Pendekatan Geometrik. Pustaka Utama. Jakarta.

Sundari, S., T. Nurhindayati, dan I. Trisnawati. 2011. Isolasi dan Identifikasi Mikoriza Indegenous dari Perakaran Tembakau Sawah (Nicotiana tabacum L.) di Area Persawahan Kabupaten Madura. Fakultas Matematika dan Ilmu Pengetahuan Alam, Institut Teknologi Sepuluh November.

Syafna. 1996. Pengaruh penggenangan, pemupukan nnitrogen dan interval pemotongan terhadap pertumbuhan dan produksi rumput lokal kumpai (Hymenachne amplexicaulis (Rudge) Nees.). Thesis. Program Pasca Sarjana Institut Pertanian Bogor. Bogor.
Syafria, H. 1998. Pengaruh pemupukan nitrogen dan interval pemotongan terhadap pertumbuhan dan perkembangan rumput lokal kumpai (Hymenachne amplexicaulis (Rudge) Nees.). Laporan Hasil Penelitian Kerja Sama Proyek Pengembangan Sebelas Lembaga Pendidikan Tinggi (ADB Loan). Jambi.

Syafna. H. 2001. Studi Kompetisi antara Alang-alang (Imperata cylindrical (L) Raeshel.) dengan Rumput Lokal Kumpai (Hymenachne amplexicaulis (Rudge) Nees.). Laporan Hasil Penelitian Fakultas Peternakan Universitas Jambi. Jambi

Syafria, H dan Jamarun, N. 2018. Pemanfaatan biourine dan fungi mikoriza arbuskula sebagai agen bioteknologi dalam meningkatkan produktivitas lahan kritis bekas tambang batubara serta pengaruhnya terhadap hasil dan kualitas hijauan Hymenachne amplexicaulis (Rudge) Nees.). Laporan Hasil Penelitian, Universitas Jambi.

Tarafdar, J. C. and Claassen. 2001. Comparative efficiency of acid phosphatase originated from plant and fungal sources. J. Plant Nut Soi. Sci. 164:279-282.

Wasaki, J., Yamamura, T. Shinano, and M. Osaki. 2003. Secreted acid phosphatase is expressed in cluster roots of lupin in response to phosphorus deficiency. Plant Soil 248; 129-136.

Yun, S. J. and S. M. Kaeppler. 2001. Induction of maize acid phosphatase activities under phosphorus starvation. Plant Soil. 237: 109-115. 